\title{
Penerapan Sanksi Pidana terhadap Anak Pelaku Tindak Pidana Pencabulan
}

\section{Renna Prisdawati}

Program Studi Hukum, Fakultas Hukum, Universitas Muhammadiyah Yogyakarta

Email : renna.prisdawati.2015@law.umy.ac.id

\author{
Info Artikel \\ Riwayat: \\ Diajukan : 20 Agustus 2020 \\ Direview : 29 September 2020 \\ Direvisi : 20 Oktober 2020 \\ Diterima : 30 November 2020 \\ Kata Kunci : \\ anak pelaku tindak pidana; \\ tindak pidana pencabulan; \\ penegakan hukum \\ DOI: \\ 10.18196/ijclc.v1i3.9609
}

\begin{abstract}
Abstrak
Pencabulan adalah semua perbuatan yang berkenaan dengan kehidupan di bidang seksual yang melanggar kesusilaan (kesopanan). Kitab Undang-Undang Hukum Pidana menggolongkan tindak pidana pencabulan kedalam tindak pidana kesusilaan. Tindak pidana pencabulan saat ini banyak terjadi dan sangat memperhatinkan. Anak yang melakukan tindak pidana sudah selayaknya jika diberikan sanksi yang disesuaikan dengan peraturan yang berlaku.Tujuan penelitian yang dilakukan penulis ini untuk mengetahui bagaimana penerapan sanksi pidana terhadap anak sebagai pelaku tindak pidana pencabulan. Jenis penelitian yang digunakan dalam penulisan ini menggunakan jenis penelitian normatif, yaitu menggunakan bahan kepustakaan, baik itu bahan primer, sekunder maupun tersier. Hasil penelitian menjelaskan bahwa upaya diversi tidak dapat dilakukan terhadap anak sebagai pelaku tindak pidana pencabulan. Sesuai dengan aturan dalam Pasal 7 ayat (2) Undang-undang Nomor 11 Tahun 2012 Tentang Sistem Peradilan Pidana Anak, syarat agar dapat dilakukan diversi hanya terhadap tindak pidana dengan ancaman pidana penjara dibawah tujuh tahun dan tindak pidana tersebut bukanlah pengulangan tindak pidana. Hal tersebut jelas tidak dapat diterapkan dalam tindak pidana pencabulan, karena tindak pidana pencabulan diancam dengan pidana penjara paling lama lima belas tahun.
\end{abstract}

\section{Pendahuluan}

Teknologi yang semakin maju tidak hanya membawa dampak positif tetapi dapat juga membawa dampak negatif. Dampak positif akan selalu memberikan kemudahan bagi seseorang untuk mengakses apapun yang terdapat di internet dan dalam sekejap juga memperoleh informasi terkini dari seluruh dunia. Sedangkan dampak negatif dapat terjadi terutama bagi anak adalah, anak dengan memudah dapat mengakses konten-konten yang bermuatan seksual yang dapat menganggu kondisi anak dan menjadikan anak sebagai korban bahkan sebagai pelaku. Dampak tersebut dapat melatarbelakangi terjadinya kenakalan remaja.

Dewasa ini kenakalan remaja semakin meningkat dan sangat memprihatinkan. Kenakalan yang di lakukan oleh remaja tersebut tidak biasa atau tidak seharusnya dilakukan oleh anak remaja karena mengarah pada tindak kriminal yang tidak sesuai dengan norma yang berlaku dalam masyarakat. Salah satu kejahatan yang dapat dilakukan oleh anak adalah tindak pidana pencabulan. Tindak pidana pencabulan adalah suatu kejahatan dengan cara melampiaskan nafsu seksual, yang dilakukan oleh seorang laki-laki terhadap seorang perempuan dengan cara melanggar hukum dan norma kesusilaan yang berlaku. ${ }^{1}$

Perbuatan cabul sebagaimana dijelaskan dalam Pasal 390 Rancangan Undang-Undang KUHP yang diambil dari Pasal 29 KUHP adalah dalam lingkungan nafsu birahi kelamin, misalnya :

\footnotetext{
${ }^{1}$ Laden Marpuang, 2004, Kejahatan Terhadap Kesusilaan dan Masalah Prevensinya, Jakarta : Sinar grafika, hlm 50
} 
a. Seorang laki-laki dengan paksa menarik tangan seorang wanita dan menyentuhkan pada alat kelaminnya.

b. Seorang laki-laki merabai badan seorang anak perempuan atau sorang wanita dan kemudian membuka kancing baju anak tersebut untuk dapat mengelus dadanya dan menciumnya. Pelaku melakukan tersebut untuk memuaskan nafsu seksualnya. ${ }^{2}$

Perbuatan cabul menurut R. Soesilo, diartikan sebagai segala perbuatan yang melanggar kesusilaan ( kesopanan ) atau perbuatan yang keji, semuanya itu dalam lingkungan nafsu birahi kelaminan misalnya cium-ciuman, meraba-raba anggota tubuh, alat kelamin dan lain-lain. ${ }^{3}$ Hart Rossi mendefinisikan pelecehan seksual sebagai perbuatan yang melibatkan orang dewasa sebagai pelaku pelecehan, tetapi pelecehan juga bisa terjadi ketika seorang anak digunakan sebagai objek pemuas seksual oleh anak lain yang berumur kurang dari 18 (delapan belas) tahun yang mengambil alih tugas sementara orang tua. ${ }^{4}$

Berdasarkan pengertian tersebut dapat di simpulkan bahwa pencabulan dilakukan oleh orang dewasa sebagai pelaku kepada korban yang masih anak-anak. Namun dalam perkembangannya, ternyata anak-anak tidak hanya dapat sebagai korban melainkan dapat juga sebagai pihak yang melakukan tindak pidana pencabulan. Pasal 28 b ayat (2) Undang-Undang Dasar 1945, bahwa setiap anak berhak atas kelangsungan hidup, tumbuh dan berkembang serta berhak atas perlindungan dari kekerasan dan diskriminasi. ${ }^{5}$ Ketentuan pasal tersebut tentu akan bertentangan dengan fakta yang ada bahwa ternyata anak dapat tereksploitasi secara seksual baik sebagai korban maupun sebagai pelaku. Berdasarkan latar belakang di atas tulisan ini akan menjelaskan lebih lanjut, bagaimana penerapan sanksi pidana jika anak melakukan tindak pidana pencabulan yang akan dilihat dari undang-undang sistem peradilan pidana anak.

\section{Rumusan Masalah}

Bagaimana penerapan sanksi pidana terhadap anak sebagai pelaku tindak pidana pencabulan?

\section{Metode Penelitian}

Metode penelitian yang digunakan adalah metode penelitian normatif, yaitu penelitian yang meletakkan hukum sebagai sebuah bangunan sistem norma. Sistem norma yang dimaksud adalah mengenai asas-asas, norma, kaidah dari peraturan perundangan, putusan pengadilan,dan semua dokumen yang merupakan informasi, atau kajian yang berkaitan dengan penelitian ini, yaitu seminarseminar, jurnal-jurnal hukum, majalah-majalah, artikel-artikel, karya tulis ilmiah, dan beberapa sumber dari internet seperti kamus dan ensiklopedia yang relevan.

\section{Hasil Penelitian dan Analisis}

Sanksi pidana adalah suatu hukuman sebab akibat, sebab adalah kasusnya dan akibat adalah hukumnya, seseorang yang terkena akibat akan memperoleh sanksi baik masuk penjara ataupun terkena hukuman lain dari pihak berwajib. Sanksi pidana merupakan suatu jenis sanksi yang bersifat nestapa yang diancamkan atau dikenakan terhadap perbuatan atau pelaku perbuatan pidana ataupun tindak pidana yang dapat menggangu atau membahayakan kepentingan hukum. Sanksi pidana pada dasarnya merupakan suatu jaminan untuk merehabilitasi perilaku dari pelaku kejahatan tersebut, namun tidak jarang bahwa sanksi pidana diciptakan dari suatu ancaman dari kebebasan manusia itu sendiri.

\footnotetext{
${ }^{2}$ Soedarso, 1992, Kamus Hukum, Jakarta : Rineka Cipta, hlm 65

${ }^{3}$ R. Soesilo, 1981, Kitab Undang-Undang Hukum Pidana (KUHP) Serta Komentar-Komentarnya Lengkap Pasal Demi Pasal, Bogor, hlm 216

${ }^{4}$ Michael Gurian, 1996, The Wonder of Boys: Cara Membesar Anak Laki-laki Menjadi Pria Sejati, Jakarta: Serambi, hal. 420.

${ }_{5}^{5}$ Desshinta Glady, "Pasal 28 b Ayat (2)", Diakses Pada Selasa 03 Desember 2014, https://www.kompasiana.com/desshintaglady/54f5e4b6a33311ee768b4590/Pasal -28-b-ayat-2
} 
Penggunaan istilah pidana itu sendiri diartikan sebagai sanksi pidana. Untuk pengertian yang sama, sering juga digunakan istilah lain yaitu hukuman, penghukuman, pemidanaan, penjatuhan hukuman, pemberian pidana, dan hukuman pidana.

Dalam kamus " black's law dictionary" dikatakan bahwa pidana adalah setiap denda atau hukuman yang dijatuhkan pada seseorang melalui sebuah kekuasaan suatu hukum dan vonis serta putusan sebuah pengadilan bagi tindak pidana atau pelanggaran yang dilakukan olehnya, atau karena kelalaiannya terhadap suatu kewajiban yang dibebankan oleh aturan hukum. Dengan demikian dapat disimpulkan bahwa pidana mengandung unsur-unsur dan ciri-ciri sebagai berikut :

a. Pidana itu pada hakikatnya merupakan suatu pengenaan penderitaan atau nestapa atau akibat-akibat lain yang tidak menyenangkan.

b. Pidana itu diberikan dengan sengaja oleh orang atau badan yang mempunyai kekuasaan (oleh yang berwenang ).

c. Pidana itu dikenakan kepada seseorang yang telah melakukan tindak pidana menurut UndangUndang.

d. Pidana itu merupakan pernyataan pencelaan oleh negara atas diri seseorang karena telah melanggar hukum.

Berdasarkan ciri-ciri diatas maka dapat diartikan bahwa pengertian sanksi pidana adalah pengenaan suatu derita kepada seseorang yang dinyatakan bersalah dalam melakukan suatu tindak pidana atau perbuatan pidana melalui suatu rangkaian proses peradilan oleh kekuasaan atau hukum. Dalam Kitab Undang-Undang Hukum Pidana (KUHP) ditegaskan bahwa seseorang dapat dipertanggungjawabkan perbuatannya karena adanya kesadaran diri dari yang bersangkutan dan ia juga telah mengerti bahwa perbuatan itu terlarang menurut hukum yang berlaku.

Sanksi sendiri diartikan oleh penulis adalah hukuman yang diterima dan harus dijalani sebagai pertanggungjawaban perbuatan yang di lakukan. Disini kita membicarakan tentang sanksi dan pemidanaan yang harus diterima oleh anak sebagai pelaku tindak pidana pencabulan. Menurut penulis perbuatan yang dilakukan oleh anak bukan hanya dilakukan untuk melampiaskan hawa nafsunya saja, tetapi terdapat unsur lain seperti ingin mencoba karena keingintahuannya yang tinggi, pernah melihat dan lain sebagainya .

Penerapan sanksi pidana terhadap pelaku tindak pidana pencabulan tidak hanya terhadap orang dewasa saja, tetapi juga diterapkan terhadap anak pelaku tindak pidana pencabulan. Pengertian tentang anak dapat ditemukan dalam Undang-Undang Republik Indonesia Nomor 35 Tahun 2014 tentang Perlindungan Anak (disingkat UUPA). Pasal 1 angka 1 UUPA memberikan pengertian atas anak sebagai seseorang yang belum berusia 18 (delapan belas) tahun, termasuk yang masih berada dalam kandungan.

Dalam hal anak sebagai pelaku tindak pidana pencabulan, digunakan Undang-Undang Nomor 11 Tahun 2012 tentang Sistem Peradilan Pidana Anak. Anak yang berkonflik dengan hukum adalah anak yang telah berumur 12 (dua belas) tahun, tetapi belum berumur 18 (delapan belas) tahun yang diduga melakukan tindak pidana. Dalam hal anak yang melakukan tindak pidana pencabulan dengan diawali rayuan-rayuan terlebih dahulu terhadap korbannya, maka perbuatan tersebut melanggar Pasal 76E UUPA, yang menyatakan:

“Setiap orang dilarang melakukan kekerasan atau ancaman kekerasan, memaksa, melakukan tipu muslihat, melakukan serangkaian kebohongan atau membujuk Anak untuk melakukan atau membiarkan dilakukan perbuatan cabul".

Hukuman bagi yang melanggar Pasal 76E UUPA, diatur dalam Pasal 82 UUPA adalah:

(1) Setiap orang yang melanggar ketentuan sebagaimana dimaksud dalam Pasal 76E dipidana dengan pidana penjara paling singkat 5 (lima) tahun dan paling lama 15 (lima belas) tahun dan denda paling banyak Rp 5.000.000.000,- (lima milyar rupiah).

(2) Dalam hal tindak pidana sebagaimana dimaksud pada ayat (1) dilakukan oleh Orang Tua, Wali, Pengasuh Anak, pendidik atau tenaga kependidikan, maka pidananya ditambah 1/3 (sepertiga) dari ancaman pidana sebagaimana dimaksud pada ayat (1). 
Anak yang melakukan tindak pidana akan dikenai pertanggungjawaban apabila usianya telah mencapai 14 tahun. Apabila usia anak diatas 12 tahun tetapi belum 14 tahun maka ketika melakukan tindak pidana sanksi yang dijatuhkan hanya berupa tindakan paling lama $1 / 2$ (setengah) dari pidana penjara orang dewasa ( Pasal 69 ayat 2 Undang-undang Nomor 11 Tahun 2012 Tentang Sistem Peradilan Pidana Anak. ). Hal ini sejalan dengan istilah double track sistem dalam hukum pidana anak yang berarti anak yang melakukan tindak pidana dapat dijatuhkan sanki berupa pidana ataupun tindakan.

Jenis sanksi pidana dalam UUSPPA diatur dalam pasal 71 yang terdiri dari pidana pokok dan pidana tambahan.

Pidana pokok terdiri dari :

a. Pidana peringatan

b. Pidana dengan syarat (pembinaan diluar lembaga, pelayanan masyarakat atau pengawasan)

c. Pelatihan kerja

d. Pembinaan dalam lembaga, dan

e. Penjara

Pidana tambahan terdiri dari :

a. Perampasan keuntungan yang diperoleh dari tindak pidana

b. Pemenuhan kewajiban adat

Pasal 81 ayat 2 UUSPPA menegaskan pidana penjara yang dijatuhkan kepada anak paling lama $1 / 2$ (satu perdua) dari maksimum ancaman pidana penjara bagi orang dewasa. Pasal 81 ayat 6 UUSPPA ditegaskan bahwa jika tindak pidana yang dilakukan anak merupakan tindak pidana yang diancam dengan pidana mati atau pidana penjara seumur hidup, pidana yang dijatuhkan adalah pidana penjara paling lama 10 (sepuluh) tahun.

Sementara itu, dalam Kitab Undang-Undang Hukum Pidana (KUHP) ditegaskan bahwa seseorang dapat dipertanggungjawabkan perbuatannya karena adanya kesadaran diri dari yang bersangkutan dan ia juga telah mengerti bahwa perbuatan itu terlarang menurut hukum yang berlaku. Dalam hal tindak pidana pencabulan yang dilakukan oleh anak, berdasarkan Pasal 82 ayat (1) UUPA, tidak ada alasan untuk menghapuskan pidana bagi si anak dan mampu bertanggungjawab (sehat jasmani dan rohani).

Bentuk sanksi tindakan yang dijatuhkan kepada anak berdasarkan Pasal 82 ayat 1 Undangundang Nomor 11 Tahun 2012 tentang Sistem Peradilan Pidana Anak meliputi :

a. Pengembalian kepada orang tua / wali

b. Penyerahan kepada seseorang

c. Perawatan dirumah sakit jiwa

d. Perawatan di LPKS

e. Kewajiban mengikuti pendidikan formal dan/ atau pelatihan yang diadakan oleh pemerintah atau badan swasta

f. Pencabutan surat ijin pengemudi dan/atau

g. Perbaikan akibat tindak pidana ${ }^{6}$

UUSPPA berupaya mengimplementasikan keadilan restoratif melalui jalan diversi dalam menangani anak yang berkonflik dengan hukum. Hal ini sebagai upaya pemenuhan dan perlindungan hak-hak anak indonesia sebagaimana terdapat dalam Undang-Undang Dasar 1945, Konvensi Hak Anak, Undang-Undang Hak Asasi Manusia dan Undang-Undang Perlindungan Anak.

\footnotetext{
${ }^{6}$ Sonia Jasmine, “Tindakan Hukum Terhadap Anak Yang Melakukan Pencabulan”, Jurnal Hukum UAJY, Volume 1, Nomor 1, (2016).
} 
Pertanggungjawaban terhadap anak dibawah umur, setelah pasal 45, 46 dan 47 KUHP dicabut, KUHP masih belum juga mengatur secara jelas tentang kedewasaan anak. Sebagai perbandingan bahwa pasal 45, pasal 46 dan pasal 47 KUHP, ditentukan bahwa anak dibawah umur yang melakukan tindak pidana :

a. Jika tindak pidana dilakukan oleh anak berusia 9 tahun sampai 13 tahun ,disarankan kepada hakim untuk mengembalikan anak kepada orang tua atau walinya dengan tanpa dipidana

b. Jika tindak pidana tersebut dilakukan oleh anak yang masih berusia 13 tahun sampai 15 tahun dan tindak pidananya masih dalam tingkat pelanggaran sebagaimana yang diatur dalam pasal 489, 490, 492, 496, 497, 503, 505, 514, 517, 519, 526, 531, 532, 536, dan 540 KUHP, hakim dapat memerintahkan agar pelaku diserahkan kepada pemerintah atau badan hukum swasta untuk di didik sampai berusia 18 tahun.

Hakim menjatuhkan hukuman terhadap pelaku, maka maksimal hukuman utama dikurangi sepertiga, jika perbuatannya diancam hukuman mati, dapat dijatuhi pidana selama-lamanya 15 tahun dan hukuman tambahan sebagaimana yang disebutkan dalam pasal 10 KUHP huruf b angka 1 dan 3 tidak dijatuhkan pasal $47 \mathrm{KUHP}$.

Sudarto mengemukakan bahwa di dalam peradilan anak terdapat aktivitas pemeriksaan dan pemutusan perkara yang tertuju pada kepentingan anak, yaitu segala aktivitas yang dilakukan oleh polisi, jaksa, hakim dan pejabat lainnya, harus didasarkan pada suatu prinsip ialah demi kesejahteraan anak dan kepentingan anak. ${ }^{7}$

Undang-undang Nomor 11 Tahun 2012 Tentang Sistem Peradilan Pidana Anak berupaya mengimplementasikan keadilan restoratif melalui jalan diversi dalam menangani anak yang berkonflik dengan hukum. Dalam sistem peradilan pidana anak wajib diupayakan diversi mulai dari tingkat penyidikan, penuntutan dan pemeriksaan perkara di persidangan. Tujuan diupayakannya diversi terdapat dalam Pasal 6 Undang-undang Nomor 11 Tahun 2012 Tentang Sistem Peradilan Pidana Anak., yaitu:

a. Mencapai perdamaian antara korban dan Anak

b. Menyelesaikan perkara Anak di luar proses peradilan

c. Menghindarkan Anak dari perampasan kemerdekaan

d. Mendorong masyarakat untuk berpartisipasi

e. Menanamkan rasa tanggung jawab kepada anak

Untuk pelaksanaan diversi terhadap Anak yang Berkonflik dengan Hukum ada syarat yang harus dipenuhi. Hal ini diatur dalam Pasal 7 ayat (2) Undang-undang Nomor 11 Tahun 2012 Tentang Sistem Peradilan Pidana Anak yang menyebutkan bahwa diversi hanya dapat diupayakan terhadap tindak pidana yang diancam dengan pidana penjara dibawah 7 (tujuh) tahun dan bukan merupakan pengulangan tindak pidana. Syarat ini bersifat kumulatif atau harus terpenuhi kedua-duanya, apabila salah satu saja tidak terpenuhi maka diversi tidak dapat diterapkan.

Dalam kasus tindak pidana pencabulan yang dilakukan oleh anak yang melanggar Pasal $76 \mathrm{E}$ UUPA, maka diversi tidak dapat diupayakan, karena dalam kasus ini bagi pelanggar Pasal 76 UUPA dijerat dengan pidana penjara paling lama 15 (lima belas) tahun dan denda paling banyak Rp 5.000.000.000,(lima milyar rupiah) (Pasal 82 ayat (1) UUPA).

Oleh karena itu, dalam kasus tindak pidana pencabulan yang dilakukan oleh anak, hakim tidak dapat memberikan putusan berupa diversi, tetapi berupa sanksi tindakan sesuai dengan Pasal 82 ayat (1) Undang-undang Nomor 11 Tahun 2012 Tentang Sistem Peradilan Pidana Anak.

\section{Simpulan}

\footnotetext{
${ }^{7}$ Sudarto, 1981, Kapita Selekta Hukum Pidana, Bandung: Alumni, hal. 129.
} 
Tindak pidana pencabulan yang dilakukan oleh anak merupakan masalah yang sangat kompleks dibandingkan dengan tindak pidana yang dilakukan oleh orang dewasa. Hal ini dikarenakan Anak adalah calon penerus generasi bangsa. Jika sejak kecil mereka telah direcoki oleh hal-hal yang merusak mental mereka, maka akan menjadi apa mereka saat dewasa nanti. Oleh karena itu, untuk melindungi hak-hak anak Indonesia, maka pemerintah menetapkan UUPA dan Undang-undang Nomor 11 Tahun 2012 Tentang Sistem Peradilan Pidana Anak. agar hak-hak Anak yang Berkonflik dengan Hukum dapat tetap terlindungi. Dalam hal anak melakukan tindak pidana pencabulan tidak dapat diupayakan diversi. Sesuai dengan aturan dalam Pasal 7 ayat (2) Undang-undang Nomor 11 Tahun 2012 Tentang Sistem Peradilan Pidana Anak. bahwa diversi hanya dapat diberikan kepada anak yang melakukan tindak pidana dengan pidana penjara dibawah 7 (tujuh ) tahun dan bukan merupakan pengulangan tindak pidana. Sedangkan dalam hal pencabulan, terhadap pelaku tindak pidana dikenakan pidana penjara paling lama 15 (lima belas) tahun, maka dari itu diversi tidak dapat diterapkan bagi anak yang melakukan tindak pidana pencabulan.

\title{
Daftar Pustaka
}

\section{Buku}

Hosianna, 2012, Perlindungan Hukum Terhadap Anak Korban Tindak Pidana Perkosaan yang dilakukan oleh anak dibawah umur, Varia Peradilan,XXVINO.325.

Laden Marpuang, 2004, Kejahatan Terhadap Kesusilaan dan Masalah Prevensinya, Jakarta : Sinar grafika

Michael Gurian, 1996, The Wonder of Boys: Cara Membesar Anak Laki-laki Menjadi Pria Sejati, Jakarta : Serambi

M.Nasir Djamil,2012, Anak BuKan Untuk Di Hukum, Jakarta:Sinar Grafika

R. Soesilo, 1981, Kitab Undang-Undang Hukum Pidana (KUHP) Serta Komentar-Komentarnya Lengkap Pasal Demi Pasal , Bogor

Setya Wahyudi, 2011, Implementasi ide Diversi Dalam Pembaruan Sistem Peradilan pidana Anak Di Indonesia, Yogyakarta: Genta Publishing.

Sudarto, 1981, Kapita Selekta Hukum Pidana, Bandung: Alumn.

Soedarso, 1992, Kamus Hukum, Jakarta : Rineka Cipta

Soedikno Martokusumo, 2005, Mengenal Suatu Hukum Pengantar. Yogyakarta : Liberty

Wagiati Soetdjo, 2005, Hukum Pidana Anak, Bandung:PT Rafika Aditama

Jurnal

Bilher Hutahaean, "Penerapan Sanki Pidana Bagi Pelaku Tindak Pidana Anak", Jurnal Yudisial, Volume 6, Nomor 1, (2013).

Sonia Jasmine, “Tindakan Hukum Terhadap Anak Yang Melakukan Pencabulan”, Jurnal Hukum UAJY, Volume 1, Nomor 1, (2016).

\author{
Undang-Undang \\ Undang-Undang Dasar Negara Republik Indonesia Tahun 1945 \\ Undang-Undang Nomor 1 Tahun 1946 Tentang Peraturan Hukum Pidana \\ Undang-Undang Nomor 8 Tahun 1981 Tentang Hukum Acara Pidana (KUHAP) \\ Undang-Undang Nomor 9 Tahun 1999 Tentang Hak Asasi Manusia \\ Undang-Undang Nomor 23 Tahun 2002 Tentang Perlindungn Anak
}


Undang-Undang Nomor 31 Tahun 2014 Tentang Perubahan Atas Undang-Undang Nomor 23 Tahun 2002 Tentang Perlindungan Anak

Undang-Undang Nomor 11 Tahun 2012 Tentang Sistem Peradilan Pidana Anak

Undang-Undang Nomor 48 Tahun 2009 Tentang Kekuasaan Kehakiman

\section{Internet}

Desshinta Glady, "Pasal 28 b Ayat (2)”, Diakses Pada Selasa 03 Desember 2014, https://www.kompasiana.com/desshintaglady/54f5e4b6a33311ee768b4590/Pasal -28-b-ayat-2

Hukum Undang-Undang Republik Indonesia Nomor 35 Tahun 2014 Tentang Perubahan Atas UndangUndang Nomor 23 Tahun 2002 Tentang Perlindungan Anak, / http://www.kpai.go.id 